TITLE:

\title{
A NEW SPECIES OF ELYSIA FROM KII, JAPAN (OPISTHOBRANCHIA- SACOGLOSSA)
}

$\operatorname{AUTHOR}(\mathrm{S})$ :

Hamatani, Iwao

CITATION:

Hamatani, Iwao. A NEW SPECIES OF ELYSIA FROM KII, JAPAN (OPISTHOBRANCHIASACOGLOSSA). PUBLICATIONS OF THE SETO MARINE BIOLOGICAL LABORATORY 1968, 16(1): 51-54

ISSUE DATE:

1968-06-29

URL:

http://hdl.handle.net/2433/175490

RIGHT: 


\title{
A NEW SPECIES OF ELYSIA FROM KII, JAPAN (OPISTHOBRANCHIA-SACOGLOSSA)
}

\author{
Iw AO HAMATANI \\ Biological Laboratory, Tennôji Senior High School attached to \\ Osaka Kyôiku University, Osaka
}

With 2 Text-figures

Two specimens of a sacoglossan, Elysia sp., collected by me from Seto, Kii, Middle Japan, are suggested here to represent a new species which is distinguished from any other members of the genus definitely by the possession of warty protuberances on the neck and pericardial regions along the median line. I would like to thank Dr. Kikutarô BABA for his generous guidance in this case of adding one more species to the faunal list of Elysia in Japanese waters compiled by him in 1957.

\section{Elysia setoensis sp. nov.}

(Japanese name: Seto-midorigai)

Holotype: Found from the shore near the Seto Marine Biological Laboratory on April 18, 1965. The animal was found crawling on a thallus of the green alga, Codium pungniformis. Collector: I. Hamatani. Fixed by Bouin's fluid in sea water for later observation and preserved in $70 \%$ alcohol. Deposited in the author's collection.

Paratype: The paratype was taken together with the holotype, but it was heavily damaged by casual putrefaction so that only its radula preparation is left at present.

Description: The holotype measures about $7 \mathrm{~mm}$ in length from the head to the tail-tip (Code Ac of Risso-Dominguez, 1963, in Eolids). Foot-corners slightly angulated. Head and neck brownish green, but more posteriorly the body appears rather to be yellowish green. There are clusters of opaque white dots on the head, parapodial margins, and tail-tip. The minute papillae on the rhinophores and parapodial lobes are opaque white. In addition to these colour ornaments, there occur circlets of reddish brown pigment on the outer surface of the body and also on that of the parapodia. These circlets are absent on the rhinophores and the inner surface of the parapodia. The sole is yellowish green with scattered reddish brown

Contributions from the Seto Marine Biological Laboratory, No. 486.

Publ. Seto Mar. Biol. Lab., XVI (1), 51-54, 1968. (Article 6) 

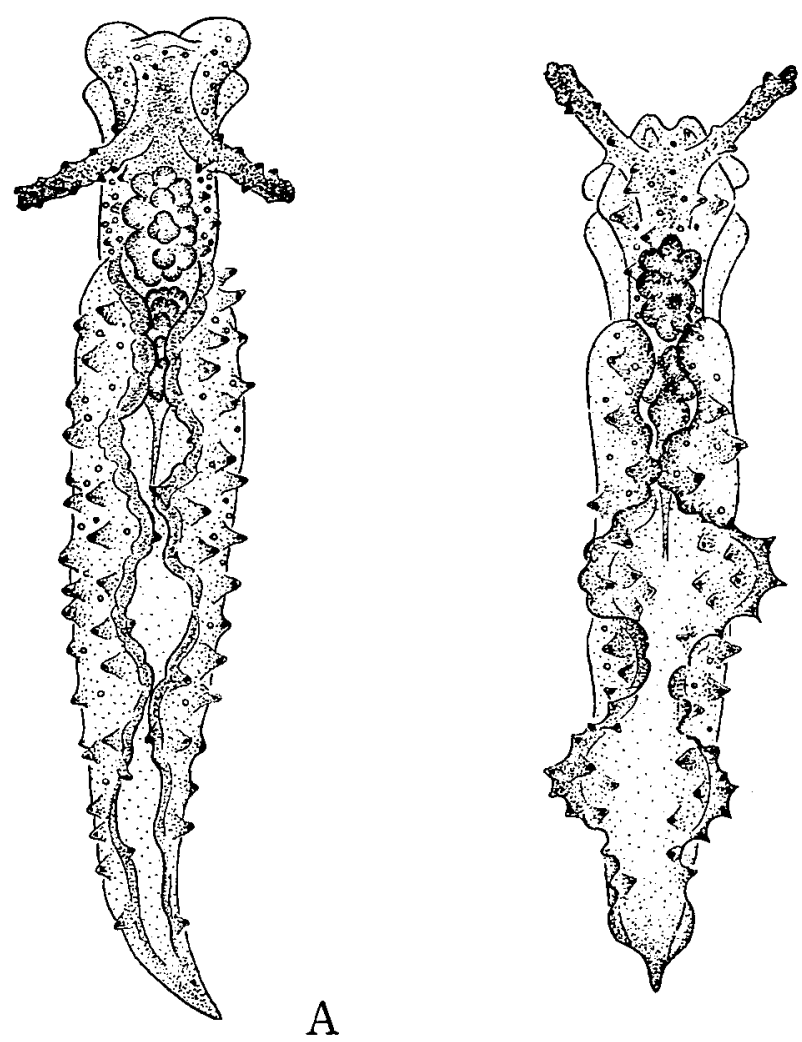

B

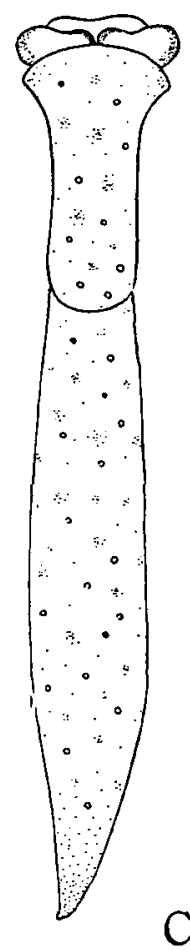

$3 \mathrm{~mm}$

Fig. 1. Elysia setoensis sp. nov.

A. Holotype, dorsal. B-C. Paratype. B dorsal, C ventral.

circlets. The wart on the neck is a colossal protuberance formed of several rounded tubercles united one another. It is opaque white in colour. A wart of the similar appearance lies along the median line just above the pericardial prominence. These warts, however, became obscure on the preserved specimen in alcohol. The parapodial margins are each apt to form a series of three inconspicuous lobes. The penial aperture opens on the right side of the neck, at about the level between the rhinophore and the eye. The anus is found just below the anterior end of the right parapodium.

The living paratype did not show any marked difference in the form and colouration of the body from the holotype, except that in the former the general tint was brownish green from the head to the main part of the body. The radula of the paratype contains about 9 teeth in the ascending series and 10 teeth in the partially injured descending series. Each tooth is finely serrulated on the ventral edge, but 


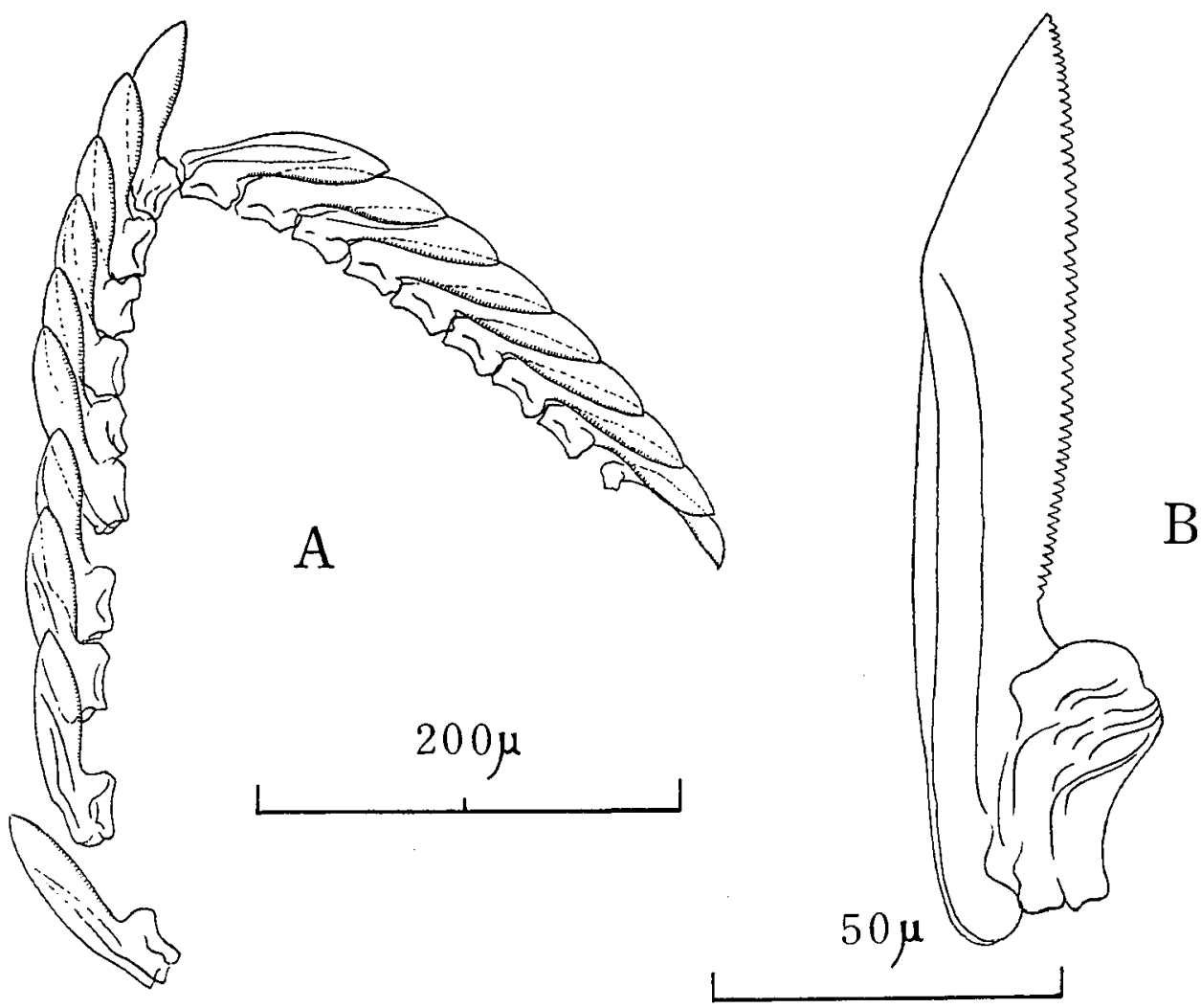

Fig. 2. Elysia setoensis sp. nov., paratype.

A. Radular teeth. B. A tooth from the descending series.

without any of lateral denticulations that were recorded by MAGNAE (1954, p. 58) on his Elysia halimedae.

Remarks: The present new species appears to be most closely allied to Elysia trisinuata BABA, 1949, in some external aspects (greenish body-colour, gently sinuated parapodial margins, etc.) and in the shape of the serrulated radular teeth, but the former is definitely separated from the latter by the existence of warty protuberances on the neck and pericardial regions as previously mentioned.

\section{LITERATURE CITED}

ABE, T. 1964. Opisthobranchia of Toyama Bay and adjacent waters. Hokuryûkan, Tôkyô.

BABA, K. 1936. Opisthobranchia of Ryûkyû (Okinawa) Islands. Journ. Dept. Agric. Kyûshû Imp. Univ., vol. 5 , no. 1 .

1937. Opisthobranchia of Japan. 1. Journ. Dept. Agric. Kyûshû Imp. Univ., vol. 5, no. 4 .

vol. 6 , no. 1 .

1938. Opisthobranchia of Kii, Middle Japan. Journ. Dept. Agric. Kyûshû Imp. Univ., 
1949. Opisthobranchia of Sagami Bay. Iwanami-shoten, Tôkyô.

1955. Opisthobranchia of Sagami Bay. Supplement. Iwanami-shoten, Tôkyô.

no. 1.

1957. The species of the genus Elysia from Japan. Publ. Seto Mar. Biol. Lab., vol. 6,

1966. Gross anatomy of the specimens of the shelled sacoglossan Volvatella (=Arthessa) collected from Okino-erabu Island, Southern Kyûshû, Japan (Nudibranchia). Publ. Seto Mar. Biol. Lab., vol. 14, no. 3.

Eurot, C. 1913. Japanese nudibranchs. Journ. Coll. Sci. Imp. Univ. Tôkyô, vol. 35, art. 1.

NaCnaE, W. 1954. On four sacoglossan molluscs new to South Africa. Ann. Natal Mus., vol. 13, pt. 1.

Marcus, Er. 1955. Opisthobranchia from Brazil. Biol. Fac. Fil. Ciên, Letr., Univ. São Paulo, Zool., nol 20.

1956. Notes on Opisthobranchia. Bol. Inst. Ocean., vol. 7.

- 1957. On Opisthobranchia from Brazil (2). Journ. Linn. Soc. Lond., Zool. vol. 43, no. 292 .

1961. Opisthobranchia Molluska from California. Veliger, vol. 3, Supplement.

Marcus, Er. \& Marcus, Ev. 1959. Opisthobranchia aus dem Roten Meer und von den Malediven. Ak. Wiss. Lit. Mainz, Nr. 12.

Marcus, Ev. \& MARcus, Er. 1960. Opisthobranchs from American Atlantic warm waters. Bull. Mar. Sci. Gulf. \& Carib., vol. 10, no. 2.

PRuvot-FoL, A. 1946. Révision critique de la famille des Elysiadae. J. de Conchyliol., vol. 87, no. 1. vol. 87, no. 3.

1947. Post scriptum a la révision critique de la famille des Elysiadae. J. de Conchyliol.,

REID, D. 1964. The reproduction of the sacoglossan opisthobranch. Proc. Zool. Soc. Lond,. vol. 143 , no. 3. 